\title{
Population ecology of Polydora ligni (Polychaeta: Spionidae). I. Seasonal variation in population characteristics and reproductive activity
}

\author{
Roman N. Zajac \\ Graduate Program in Environmental Sciences, The University of New Haven, 300 Orange Avenue, West Haven, \\ Connecticut 06516, USA
}

\begin{abstract}
A population of the polychaete Polydora ligni Webster was studied during 1982 and 1983 in Alewife Cove, Connecticut, USA, to determine seasonal changes in population characteristics. During early spring (March and April), the population was comprised of primarily large adults that had over-wintered. Females in this group exhibited the highest mean individual fecundity over the year $(>2000$ larvae per brood). However, total larval production at this time was low (5200 to 208000 larvae $\mathrm{m}^{-2}$ per $14 \mathrm{~d}$ ) due to low densities of adults. Population density increased slowly during spring as juveniles produced by overwintering adults recruited into the population and matured into adults. While mean individual fecundity of these adults was lower $\left(\approx 1200\right.$ larvae brood $\left.{ }^{-1}\right)$, larval production peaked $\left(\approx 884000\right.$ larvae $\mathrm{m}^{-2}$ ) due to their high density. Population abundance peaked coincident with peaks in larval production, decreased rapidly during late summer and leveled off during fall and winter Population density was lower and fluctuated less in the second year of the study, but general seasonal patterns were repeated. Reproductive activity was continuous over the study period. The overall female-to-male sex ratio was $2.42: 1$, and females grew to significantly larger sizes than males. Besides fecundity, there were seasonal differences in the number of gametogenic segments per female and the number of eggs per capsule; there were no seasonal differences in the number of egg capsules per brood. Temporal changes in population characteristics of $P$. ligni differed to various degrees from those reported for related taxa and other opportunistic polychaetes. However, the general patterns were similar. Seasonal variation in the population characteristics of opportunistic polychaetes may cause responses to disturbance to vary because of changing dynamics in populations that act as sources of larvae. Seasonally varying dynamics may also be an important evolutionary determinant of opportunistic life history traits.
\end{abstract}

\section{INTRODUCTION}

Studies of infaunal succession have shown several common polychaete annelids rapidly increase in abundance following natural, pollution related or experimental disturbances in estuarine and neritic waters. This group of opportunistic species includes the capitellid Capitella capitata (usually Type I) and the spionids Streblospio benedicti and Polydora ligni (e.g. Grassle \& Grassle 1974, McCall 1977, Levin 1984a). Other polychaetes, oligochaetes, bivalves and amphipods can be important infaunal opportunists, as shown in several studies (McCall 1977, Pearson \& Rosenberg 1978). However, it does appear that this trio regularly recolonizes disturbed habitats and can play an important role in early successional dynamics (e.g. Rhoads \& Boyer 1982, Gallagher et al. 1983). They have also been characterized as pollution indicators (Pearson \& Rosenberg 1978).

It is not surprising therefore, that over the past $15 \mathrm{yr}$ a number of studies have been done to elucidate the details of the ecology of Capitella capitata, Streblospio benedicti and Polydora ligni. These include, for example, studies of factors affecting life history expression (Redman 1984, Tenore \& Chesney 1985, Levin 1986a, Levin \& Creed 1986, Zajac 1986, Gremare et al. 1988), population dynamics (Chesney \& Tenore 1985a, b, Gremare et al. 1989), larval development modes (Grassle \& Grassle 1977, Levin 1984b, Levin et al. 1987), larval behavior (Butman et al. 1988) and ecologic genetics (Grassle \& Grassle 1974, 1976, 1977, Rice \& Simon 1980, Levin et al. 1991). This body of work indicates that many factors that fluctuate seasonally in the field, such as food levels, temperature, salinity, intraspecific 
density, etc., can have a significant impact on the population dynamics of these opportunistic species. Surprisingly however, there have been few studies detailing the characteristics and dynamics of field populations of C. capitata (Warren 1976, Oyenekan 1980, Tsutsumi \& Kikuchi 1984, Tsutsumi 1987), S. benedicti (FonsecaGenevois \& Cazaux 1987, Levin \& Huggett 1990 , Marsh \& Tenore 1990) and $P$. ligni. Thus, we are only beginning to interface detailed field and laboratory studies of opportunistic polychaetes in the effort to understand their population dynamics in nature.

Populations of opportunistic species can be viewed as being comprised of 2 groups: those responding to disturbance, and those found under ambient, nondisturbed conditions. The overall maintenance of their populations in soft-sediment habitats may depend on an interplay between the dynamics of populations existing under ambient conditions and those which have recently recolonized open habitat (Zajac \& Whitlatch 1991). Knowledge of the attributes, e.g. sizestructure, reproductive activity, demography, of both recolonizing and ambient populations is critical to understanding this interplay, and how it determines overall population dynamics relative to the softsediment temporal mosaic (sensu Johnson 1973).

Here, I present the results of a field study on the population ecology of Polydora ligni. The object of this study was to quantify the seasonal variations in population characteristics and reproductive activity under ambient conditions. This information serves as a framework for investigating demographic consequences of seasonal life history variation [Zajac 1991 (companion paper)] and other facets of its population ecology, and how seasonal changes in population dynamics may influence the role of $P$. ligni in community-level processes such as succession. The results presented here are also compared to what is known about the population ecology of other opportunistic infauna and polydorid polychaetes.

\section{General ecology and life cycle}

Polydora ligni is distributed along the east and west coasts of North America, Gulf of Mexico and Europe (Blake 1971). Typically found in estuaries, it inhabits various sediment types as well as hard substrates (e.g. oysters). P. ligni is tubiculous and feeds with 2 grooved palps on surface sediments and particles suspended in the water column (Dauer et al. 1981). Sexes are separate, but hermaphrodites have been found on occasion (Rice 1975, pers. obs.). Males and females produce gametes in segments within the middle half of the body, i.e. the gametogenic segments. Males release spermatophores onto the sediment surface (Rice 1978).
Females use their palps to direct the spermatophores into their tubes for storage in seminal receptacles. Fertilization is thought to occur as eggs are deposited in capsules.

Larvae are initially brooded in capsules that are deposited as a bead-like string attached to the inside of the female's tube (Blake 1969). Once a set of capsules has been deposited in the tube, a new batch of eggs begins to develop simultaneously in the female's coelom. In the capsules, embryos develop into three setiger planktotrophic larvae which are then released; they complete their development in the water column. Larvae settle at a size of 15 segments (Blake 1969). Adelphophagia, or nurse-egg feeding, occurs in several spionids (Hannerz 1956), including Polydora ligni (Blake 1969).

Rice (1975) found development in the egg capsules, from deposition of eggs to release of 3 setiger larvae took ca $4 \mathrm{~d}$ at $20^{\circ} \mathrm{C}$. Larvae metamorphosed at $18 \mathrm{~d}$ reached sexual maturity at $37 \mathrm{~d}$, and formed egg capsules by ca 53 d (Rice 1975). These results agree with studies by Anger et al. (1986) who found that at 12 and $18^{\circ} \mathrm{C}$ Polydora development from hatching to metamorphosis took 16 to $28 \mathrm{~d}$ and 9 to $11 \mathrm{~d}$, respectively, while first reproduction occurred about $33 \mathrm{~d}$ after settlement at $18^{\circ} \mathrm{C}$. Anger et al. (1986) found that the average life span of $P$, ligni in the laboratory was $13 \mathrm{mo}$.

\section{METHODS}

Study site and field sampling. Samples were taken from a shallow $(\approx 0.1$ to $0.5 \mathrm{~m}$ deep at $M L W$ ) subtidal sandflat in Alewife Cove, a small estuary in southeastern Connecticut, USA. The study site was ca $1500 \mathrm{~m}^{2}$ in area. Temperature and salinity during the study period ranged from 0 to $25^{\circ} \mathrm{C}$ and from 12 to $32 \%$. Total organic carbon in surface sediments ranged from 2.5 to $4.5 \%$ ash-free dry weight. Detailed seasonal changes in these factors are presented in Zajac (1985). Physical, chemical and ecological features of the estuary and its benthic community are also given in Welsh et al. (1978) and Zajac \& Whitlatch (1982).

Infaunal sampling was initiated on May 4, 1982 and continued until November 11, 1983. Samples were taken every 2 wk between May and November 1982, while monthly samples were taken afterward. On each sampling date, 15 core samples were taken (except as noted in Fig. 2) at random locations within the study site using a $3.4 \mathrm{~cm}$ diameter plastic tube inserted to a depth of $10 \mathrm{~cm}$. Samples were returned intact to the laboratory and fixed whole by gently extruding each sample into a glass container and adding $10 \%$ buffered formalin and Rose Bengal stain. Samples were later washed on a $212 \mu \mathrm{m}$ sieve and residues were transferred to $70 \%$ 
ethanol. Samples were sorted under a dissecting microscope at $6 \times$ to $40 \times$ magnification. All Polydora ligni individuals and tubes were sorted from the samples.

Collection of population data. Population abundance estimates of Polydora ligni were based on counts of individuals obtained from core samples. Population size-structure was based on the number of segments per individual, which was the quickest and most efficient measurement to make on whole worms (Zajac 1985). For fragmented worms, ca $15 \%$ of those collected, the number of segments (S) was estimated using the equation:

$$
\begin{aligned}
& S=52.439(W)+8.42 \\
& \left(R^{2}=0.883, p<0.0001, N=108\right)
\end{aligned}
$$

where $\mathrm{W}=$ width of the 5 th segment in $\mathrm{mm}$.

Individuals regenerating posterior segments were treated at their size at the time of sampling. The degree of tissue loss in this group of worms will be considered in another contribution. Size measurements were made under a dissecting microscope equipped with an ocular micrometer. Individuals were grouped into 6 sizeclasses including worms 15 to 32,33 to 50,51 to 60,61 to 70,71 to 80 and $80+$ segments in size.

Female worms were distinguished by the presence of developing eggs in the coelom and/or the presence of brood capsules in their tubes. Males were distinguished by the presence of sperm in the coelom which appeared as dense clumps of lighter color in the stained, preserved specimens.

Reproductive characteristics of individual females which were directly measured included the number of gametogenic segments (using only whole worms), the number of egg capsules deposited (using only intact strings of capsules) and the number of eggs per capsule (using both intact and partially intact strings of capsules). The number of eggs per capsule was determined by randomly selecting 5 capsules from each string, counting all eggs and/or larvae within each capsule and averaging these counts.

Individual fecundity (total number of eggs or larvae brooded by a female) was estimated using 3 different methods. Method A: For worms with intact strings of capsules, the mean number of eggs per capsule was multiplied by the number of capsules in the brood. Method B: For females found with only a portion of their capsule string intact, individual fecundity $(F)$ was estimated using the mean number of eggs per capsule (EPC) and the worm's segment number ( $S$ ) in the equation:

$$
\begin{aligned}
& \mathrm{F}=26.49(\mathrm{EPC})+20.42(\mathrm{~S})-1640 \\
& \left(\mathrm{R}^{2}{ }_{\text {adj }}=0.877, \mathrm{p}<0.0001, \mathrm{~N}=46\right)
\end{aligned}
$$

Method C: Fecundity was also estimated for females which had well-developed eggs in the coelom and presumably would release larvae during the period between sampling dates. The only characteristics that could provide an estimate of fecundity for the latter group of females were segment number and the number of gametogenic segments (GS). Analysis of several regression models indicated that the following quadratic model yielded the best estimate of fecundity using these 2 characteristics:

$$
\begin{aligned}
F= & -74.3(S)-90.3(G S)-0.47\left(S^{2}\right)-5.3\left(G^{2}\right) \\
& +6.6(S \times G S)+2880.2 \\
\left(R^{2}=\right. & 0.752, p<0.0001, N=45)
\end{aligned}
$$

To determine if each method yielded equivalent estimates of individual fecundity, each was applied using data for 10 randomly chosen females with fully intact broods. There were no significant differences in fecundity values estimated using the 3 methods (1-way ANOVA, model II, $F_{2,27}=0.33, p=0.723$ ).

The total number of larvae that potentially could be produced by the population at each sampling date and over intervening weeks between sampling times was based on fecundity estimates using the 3 methods described above. Fecundity estimates for individual females were summed and then divided by the number of sample cores taken on that date, yielding an estimate of total larval production per core over an interval of ca $2 \mathrm{wk}$.

Statistical analyses of population data were performed using various programs in the Statistical Analysis System (SAS 1982) and tests given in Sokal \& Rohlf (1981). Temporal fluctuations in reproductive activity were analyzed using data on females which showed no sign of adelphophagia in their broods, and/or of regenerating posterior segments. The reproductive characteristics of these females will be considered separately (Zajac in prep.). Data on female reproductive characteristics were combined into seasonal groups to analyze for general seasonal patterns. Detailed, biweekly reproductive patterns are presented in Zajac (1985). Five seasonal groups were designated based on density trends (see Fig. 1). Kruskal Wallis non-parametric tests were used to test for seasonal differences in each reproductive characteristic.

\section{RESULTS}

\section{Fluctuations in population density and structure}

Population density of Polydora ligni exhibited distinct seasonal, and year-to-year, variation during the study period (Fig. 1). Densities between sampling dates were significantly different (1-way ANOVA, $F_{24.324}=$ 26.73, $\mathrm{p}<0.0001$ ). Densities increased rapidly in late spring/early summer, 1982, declined sharply during late summer, and remained relatively low during fall and winter. Population abundance was lower during 


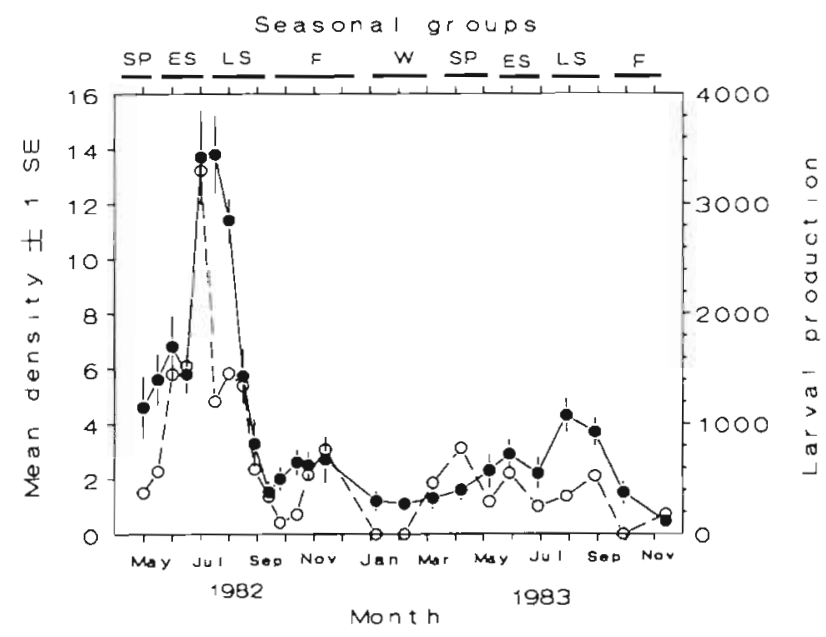

Fig. 1. Polydora ligni. Temporal fluctuations in mean ( $\pm 1 \mathrm{SE}$ ) density (-) per $9.08 \mathrm{~cm}^{2}$ in Alewife Cove between May 1982 and Nov 1983 and in the potential number of larvae produced per core (O) over each sampling period by the population. For the first 5 samples $N=10$, thereafter $N=15$. Lines above graph indicate seasonal groupings of samples used for reproductive analysis. $\mathrm{SP}=$ spring, $\mathrm{ES}=$ early summer, $\mathrm{LS}=$ late summer, $F=$ fall, $W=$ winter

1983. Density fluctuations were not as pronounced, but seasonal trends were similar to 1982 .

Newly recruited juveniles (15 to 32 segments) were present throughout the study period (Fig. 2). When females were producing broods, low numbers of recruits were found only in late August 1982 and March 1983. New recruits and juveniles, individuals prior to or just attaining sexual maturity $(33$ to 50 segments), comprised the most abundant size-classes during most of the study (Fig. 2). These 2 size classes reached peak abundances in July 1982, accounting for

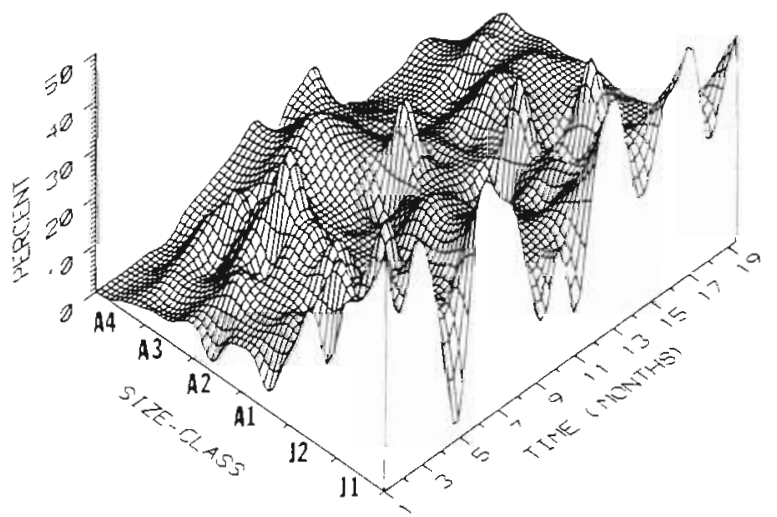

Fig. 2. Polydora ligni. Temporal fluctuations in population structure during the study period. Time is depicted as months following initiation of sampling. Worm size-classes were based on the number of segments as follows: J1: $15-32 ; \mathrm{J} 2$ 33-50; A1: 51-60; A2: 61-70; A3: 71-80; A4: 80+. The number of individuals examined for each date are given in Zajac (1985) the sharp increase in overall density at this time. Adult size-classes ( $>50$ segments) comprised most of the population when recruitment diminished during late summer 1982, and during winter 1983 when settlement ceased. Between January and March no newly settled, 15 setiger individuals were found. Individuals in the smallest size-class during this period were $>20 \mathrm{seg}-$ ments in size. Settlement resumed in April 1983, but did not attain 1982 levels. As a result, adults made up a somewhat larger proportion of the population during 1983 in comparison to 1982.

Almost no adults $>80$ segments were found between May and mid September 1982. Subsequently, these large worms were present consistently, except between June and July 1983; in April 1983, they were the most abundant adult size class in the population.

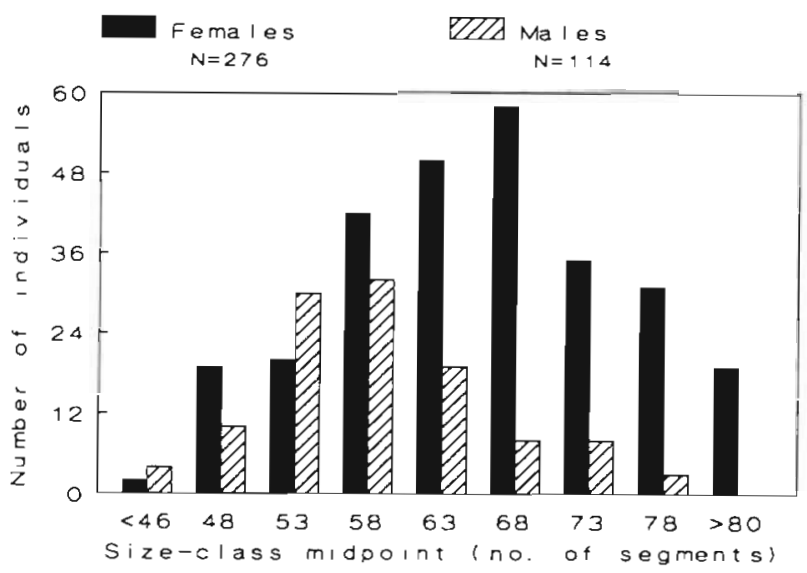

Fig. 3. Polydora ligni. Size-frequency distributions of females and males based on sexed individuals from all samples. Size based on number of segments per worm

Male and female size distributions (Fig. 3) were significantly different $\left(G=64.28, \chi^{2} 8 \mathrm{dt}=26.1, \mathrm{p}<0.001\right.$; homogeneity test, Sokal \& Rohlf 1981). Few males $>63$ segments in length were found. The 276 females vs 114 males indentified (it was not possible to accurately sex 204 adult sized individuals) suggests an overall $2.42: 1$ female-to-male sex ratio. However, the ratio for individuals up to 60 segments in size was near $1: 1$

\section{Reproductive activity}

The presence of gametes in males and females was first apparent in the 33 to 50 segment size-class. However, no worms below 45 segments contained gametes, and $65 \%$ of the individuals containing gametes in this size-class were 49 to 50 segments in size. A high proportion of worms $>50$ segments had either gametes and/or egg capsules (for female worms) throughout the study period (Fig. 4). The only period when no repro- 


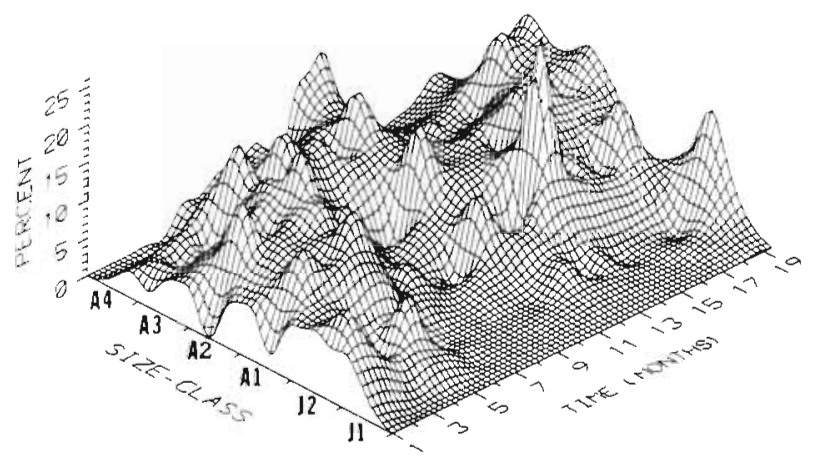

Fig. 4. Polydora ligni. Temporal fluctuation in proportion of reproductive adults in the population studied over each sizeclass. Axis labels as in Fig. 2

ductive activity was found in a large portion of the population was during mid-winter (January and February 1983). This was particularly evident in adults 51 to 70 segments in size. Adults $>70$ segments during this time had developing gametes.

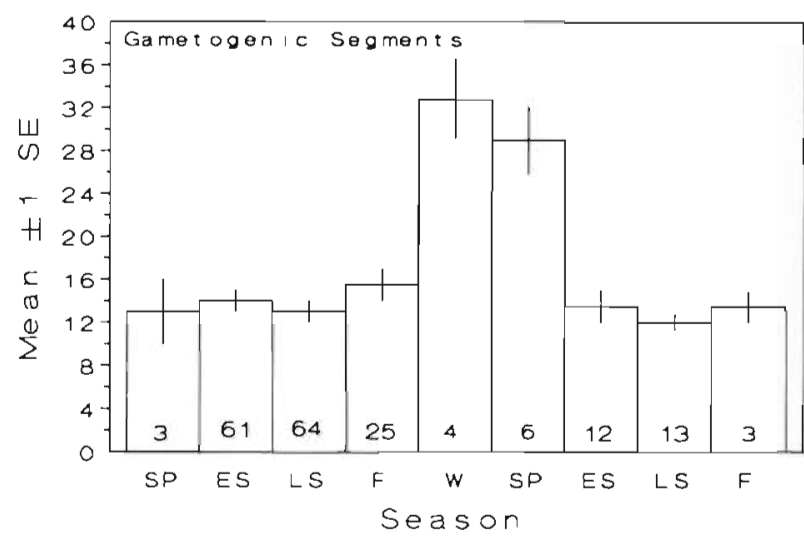

Fig. 5. Polydora ligni. Seasonal fluctuations (mean $\pm 1 \mathrm{SE}$ ) in number of gametogenic segments per female. Seasonal designations as in Fig. 1 Numbers within each histogram bar indicate sample size

Most female reproductive traits varied seasonally. The number of gametogenic segments was similar during most seasons (Fig. 5), but significant peaks were found in winter and spring $\left(\chi^{2}=13.57, \mathrm{df}=8, \mathrm{p}<0.093\right)$. There were no differences in egg-capsule production during seasons in which they were produced $\left(\chi^{2}=7.40\right.$, $\mathrm{df}=7, \mathrm{p}<0.385 ;$ Fig. 6). There were, however, significant seasonal differences in the number of eggs per capsule $\left(\chi^{2}=28.80, \mathrm{df}=7, \mathrm{p}<0.002\right)$. Peaks were observed in both spring groups and a high number of eggs per capsule was also found in fall (Fig. 7). Individual fecundity (Fig. 8) exhibited significant differences between seasons $\left(\chi^{2}=24.18, \mathrm{df}=7, \mathrm{p}<0.001\right)$, with the highest values in fall 1982 and spring 1983. Seasonal peaks in fecundity occurred concomitantly with peaks in the number of gametogenic segments and eggs per capsule.

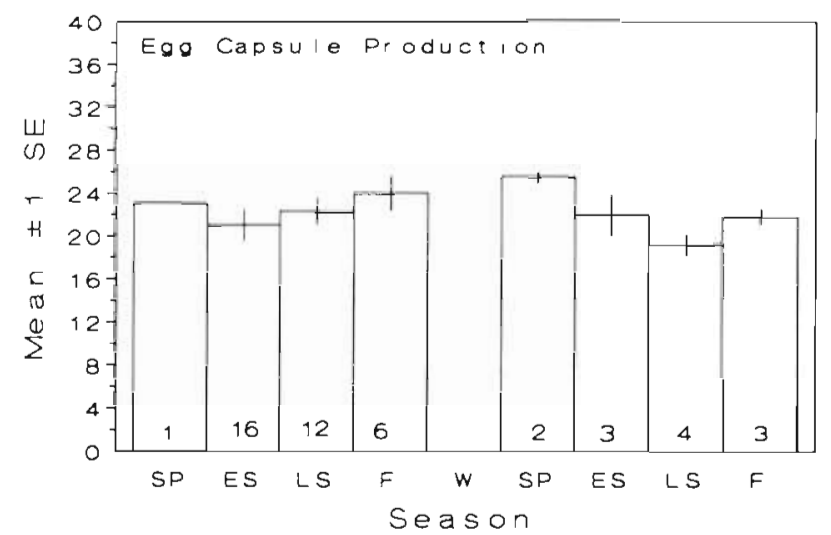

Fig. 6. Polydora ligni. Seasonal fluctuations (mean $\pm 1 \mathrm{SE}$ ) in number of capsules produced per female. Seasonal designations as in Fig. 1. Numbers within each histogram bar indicate sample size

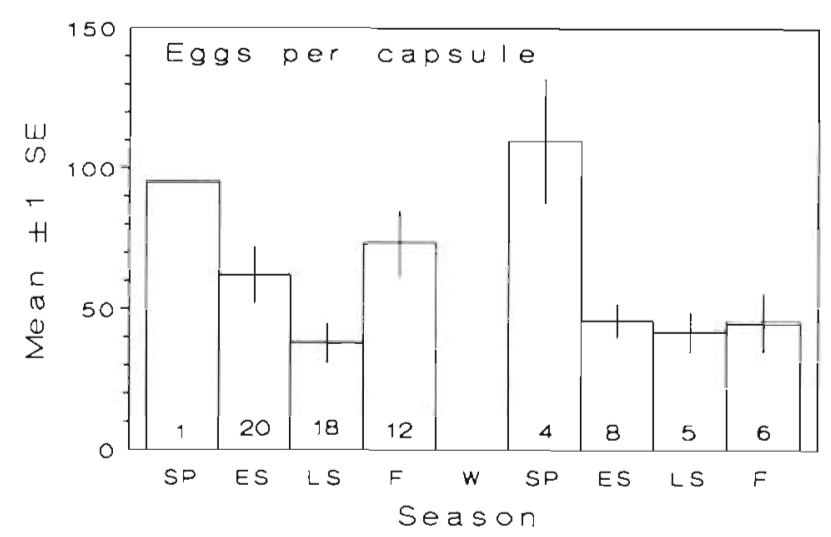

Fig. 7. Polydora ligni. Seasonal fluctuations (mean $\pm 1 \mathrm{SE}$ ) in number of eggs per capsule for individual females. Seasonal designations as in Fig. 1. Numbers within each histogram bar indicate sample sizes

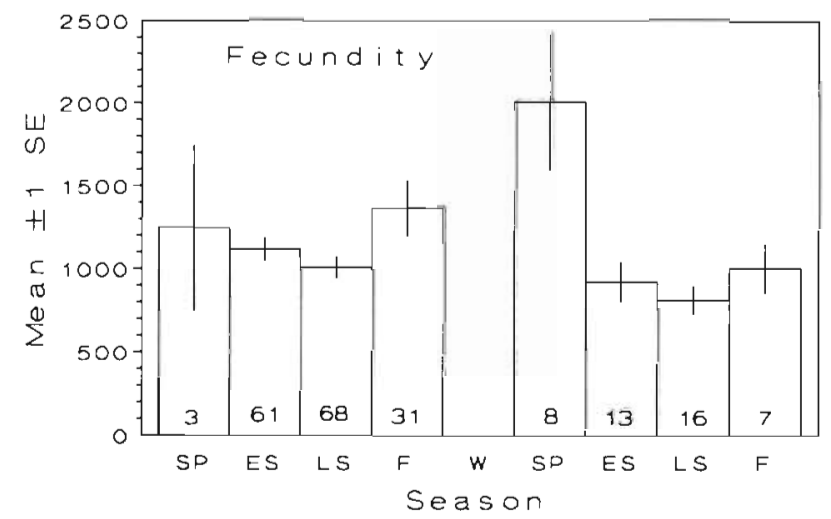

Fig. 8. Polydora ligni. Seasonal fluctuations (mean $\pm 1 \mathrm{SE}$ ) in the fecundity (number of eggs or larvae) of individual females. Seasonal designations as in Fig. 1. Numbers within each histogram bar indicate sample sizes 
There were significant seasonal differences in adult female size $\left(\chi^{2}=23.64\right.$, df $=8, p<0.001$; Fig. 9) with periods of large mean size also coinciding with peaks in fecundity (Fig. 8). However, the fecundity of Polydora ligni was not tightly related to size on an individual

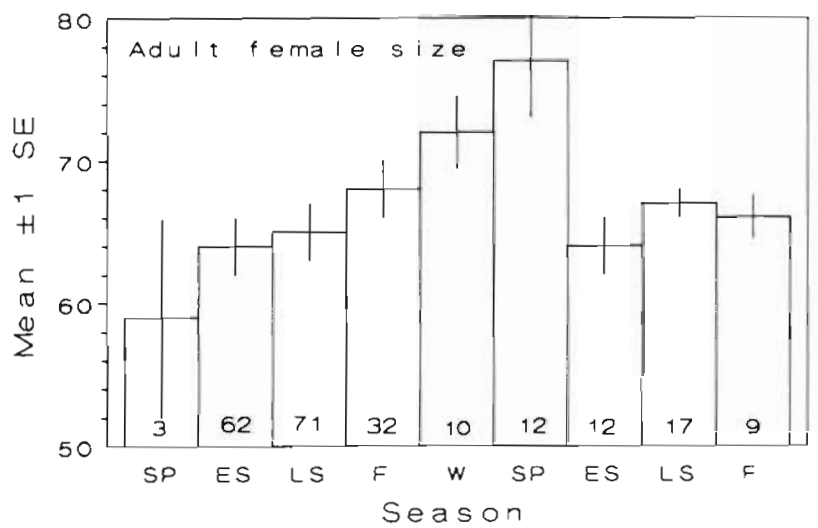

Fig. 9. Polydora ligni. Seasonal fluctuations (mean $\pm 1 \mathrm{SE}$ ) in the size of adult females. Seasonal designations as in Fig. 1. Numbers within each histogram bar indicate sample sizes

basis (Fig. 10). Although statistically significant ( $p<$ 0.001 ), size accounted for only $43 \%$ of the variation in fecundity using a linear regression model and $60 \%$ using a quadratic model (Fig. 10). Fecundity increased greatly in females $>74$ segments in size, but increased slowly below this size.

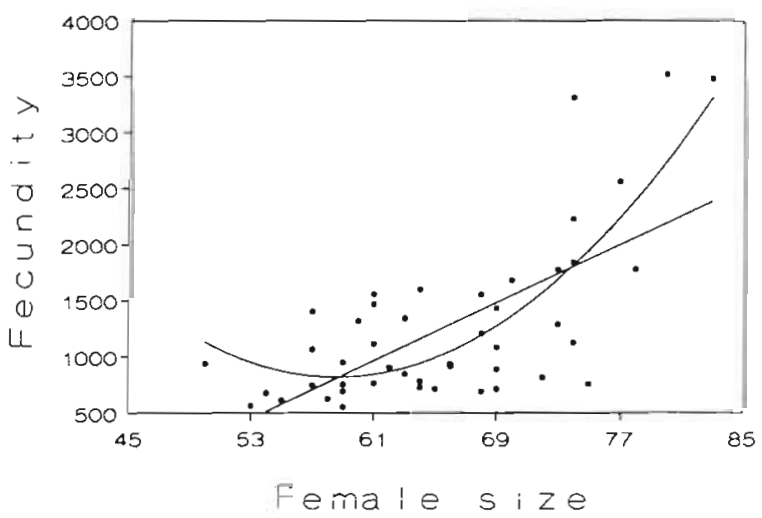

Fig. 10. Polydora ligni. Relationships between adult female size and fecundity (no. of eggs/larvae per brood). Size based on number of segments. Linear model is Fecundity $=66.8$ (TS) - 3151.8 $\left(\mathrm{R}^{2} \mathrm{adj}^{2}=0.425 . \mathrm{p}<0.001\right)$; nonlinear model is Fecundity $=-223.3(\mathrm{TS})+2.07\left(\mathrm{TS}^{2}\right)+6785.8\left(\mathrm{R}^{2}=0.597\right.$. $p<0.001) . N=46$

Fluctuations in larval production by the population coincided closely with trends in mean abundance (Fig. 1). Larval production increased sharply mid summer 1982, oscillated during fall, and was relatively low during 1983. In comparison to individual fecundity
(Fig. 8), the population produced more total offspring during summer when individual fecundity was low, but densities were high. As densities declined, individual fecundity increased, but total larval production decreased.

\section{DISCUSSION}

During this study, Polydora ligni exhibited a seasonal abundance pattern typical of infaunal populations inhabiting temperate environments (e.g. Holland 1985). Peak abundances of $P$. ligni, and of $P$. ciliata, between early and mid-summer have also been found in other habitats (Dorsett 1961, Watling 1975, Lambeck \& Valentijn 1987). Sharp decreases in abundance following the mid-summer peak were found in these studies as well, indicating that large fluctuations in abundance occur in ambient as well as recolonizing populations (Grassle \& Grassle 1974).

Peak abundance in 1982, however, was almost 3 times that found in 1983. Thus, while the mid-summer population increase appears to be predictable, the magnitude of density changes can vary. A similar yearto-year pattern for Polydora ligni was found previously in Alewife Cove (Zajac \& Whitlatch 1982). Interestingly, alternating years of high and low summer abundance are also suggested by density patterns given in Watling (1975) and Lambeck \& Valentijn (1987). While there may be an underlying biannual cycle in the peak population abundance of $P$. ligni, such cycles can be altered by factors such as disturbance, food supply, etc. (Chesney \& Tenore 1985a, Gremare et al. 1989), leading to varying population abundance patterns over the long-term (e.g. Nichols \& Thompson 1985).

Changes in population size-structure (Fig. 2) revealed that the sharp density fluctuations, on the most part, resulted from recruitment during summer and subsequent loss of juveniles during late summer and fall, due to mortality and/or growth into larger sizeclasses (Zajac 1991). The close association between increases in potential larval production and density during this period (Fig. 1) suggests that recruitment was from a local larval pool. Although little is known of the behavior of polychaete larvae in estuaries (Stancyk \& Feller 1986), a number of physical and biological factors may act to promote recruitment into parental populations (Levin 1986b). In estuarine populations, adaptation to local conditions (see below) may be accompanied by selection for mechanisms which would promote larval retention within the estuary, as export of locally adapted individuals would not be beneficial (Strathmann 1982). Infaunal opportunists have evolved a variety of larval development patterns 
which would promote retention including development in brood pouches (e.g. Streblospio benedicti), in the tube matrix (e.g. Capitella capitata), asexual reproduction (e.g. Pygospio elegans) and in brood capsules (e.g. Polydora ligni). These forms of larval development may decrease dispersal because the pelagic phase is reduced relative to broadcast spawning. The period of encapsulation also may reduce larval mortality

Individuals in the smallest size-class were found consistently over the study period, and comprised $>20 \%$ of the population in 20 out of 25 sampling dates. The relative proportion increased to $>50 \%$ in spring (May 1982, April 1983). Thus, a consistent but seasonally varying degree of recruitment resulted in juveniles dominating the population over much of the year. This pattern differs from that found for a related species, Polydora ciliata. Both Dorsett (1961) and Gudmundsson (1985) found low relative abundances of small individuals in populations of this congener. In Gudmundsson's (1985) study, the population was mostly comprised of individuals 50 to 70 segments in size throughout the year. For the $P$. ligni population studied here, this size range was most dominant only at the end of summer (September 1982) and winter (March 1983). However, Gudmundsson (1985) did note that small juveniles were found consistently over much of the year. This difference does not appear to be due to different sampling procedures since Gudmundsson sorted whole sediment samples under a dissecting microscope. Also, Daro \& Polk (1973) found newly settled $P$. ciliata on immersed microscope slides between May and September with peak settlement in June. Data presented by Lambeck \& Valentijn (1987) indicate $P$. quadrilobata juveniles dominated the population between March and April.

Size-distribution differences between sexes and sex ratios are not well known for field populations of polydorid spionids. In this study, most males were between 50 and 60 segments in maximum size, but most females grew to between 60 and 70 segments. Such differences have been found in other polychaetes (Olive 1970). The overall sex ratio of 2.4 females to 1 male found in this study is higher than the 1.17 to 1.0 ratio found by Dorsett (1961) for Polydora ciliata. The skewed ratio found for $P$. ligni here suggests sex-specific differences in survivorship and/or growth in adult worms. Other possible causes are differential production of female vs male larvae, sequential hermaphroditism in males and differences in ability of distinguishing males and females. The first 2 possibilities are not known, although some $P$. ligni hermaphrodites have been found (Rice 1975, pers. obs.). I feel the ratio is not an artifact of the methods since it was easier to distinguish males and females at larger individual sizes.

The population of Polydora ligni in Alewife Cove was reproductively active throughout much of the year as indicated by the large proportion of adults with gametes and females with brood capsules (Figs, 4 \& 6). $P$. lignican therefore be classified as a semi-continuous breeder (sensu Olive \& Clark 1978). This agrees well with studies which suggested semi-continuous reproduction in this species based on the presence of larvae in the water column during much of the year (Blake 1969, Levin 1984a).

Female Polydora ligni exhibited significant seasonal variation in reproductive traits, except for the number of egg capsules produced. Traits which appeared to be most sensitive to seasonality were those directly relating to gamete production. The number of eggs per capsule ranged from a low of about 40 in late summer to a high of about 120 in spring. The number of gametogenic segments peaked in winter and spring, but showed little variation during other times of the year. The highest fecundity also occurred in spring. Similar seasonal differences have been found in populations of $P$. ciliata. Gudmundsson (1985) found that between January and February females produced up to 2200 larvae per brood, while only 800 larvae per brood were produced between May and June. Dorsett (1961) observed that in summer females produced 17 to 18 egg capsules with 11 to 12 eggs per capsule, yielding an overall fecundity of 201 larvae per female. Females breeding during colder months produced 19 egg capsules with $\approx 60$ eggs per capsule for a total fecundity of 1140 larvae per female. Dorsett (1961) however attributed this difference to the existence of 2 geographically overlapping populations in the area adapted to different temperature regimes.

Changes in the reproductive life history traits of Polydora ligni appear to be related to seasonal changes in female size. The large size attained by females during winter and their high fecundity once reproduction resumed in spring are especially of interest. Although brood production ceased, gametogenesis continued throughout the winter. This can be an important physiological adaptation with regard to population dynamics, since it permits the build-up of gametes prior to spring. Presumably, females are able to channel energy above that required for maintenance and growth to the production of gametes, without added costs associated with brood capsule production and maintenance. Since female size also increased during this period, albeit at a much slower rate than would be found during warmer portions of the year, energy sources were being directed to both somatic and reproductive activities. The slow accumulation of gametes during winter may be an extremely efficient energetic adaptation in $P$. ligni, resulting in copious numbers of larvae being produced at the start of spring, the period most favorable for population expansion (Zajac 1991). 
Reproductive life history traits also vary on several geographical scales in Polydora ligni. Rice \& Simon (1980) studied 4 separate populations in Forida and found significant variation in the location of the first gametogenic segment, egg diameter, and the number of gametogenic segments and eggs per capsule. In addition, they found differences in several morphological traits, and growth and survivorship responses to different temperature, salinity and oxygen combinations. Values for several of the traits measured by Rice (1978) and Rice \& Simon (1980) generally fall below those found for $P$. ligni across all seasons in this study. Differences between the Floridian and Alewife Cove populations, respectively, include the number of eggs per capsule ( 30 to 60 vs 60 to 170) and adult size (35 to 50 segments vs 50 to 90 segments). Because of these differences, it is likely that brood size is also smaller in Floridian populations of $P$. ligni. Brood size also appears to be smaller in a Pacific coast population of $P$. ligni. Levin (1984a) reported a range of 200 to 400 larvae brood ${ }^{-1}$ from Mission Bay, California (USA), whereas average brood size in Alewife Cove ranged between 950 to 2000 larvae brood ${ }^{-1}$ on a seasonal basis. Blake (1969) noted up to 132 eggs capsule ${ }^{-1}$ in $P$. ligni from Maine, in close agreement with this study. It appears that New England populations of P. ligni differ in their life history traits from other geographically remote populations analogous to that found for other infaunal opportunists (Levin 1984b, Tsutsumi 1987).

Seasonal fluctuations in habitat conditions have marked effects on the life history and population dynamics of Polydora ligni. P. ligni is similar to other infaunal opportunists in several respects, and it is not surprising that seasonal life-history variation is a general feature of their ecology. Grassle \& Grassle (1974) found significant changes in fecundity and female size in Capitella capitata. High fecundity, coinciding with large female size, was evident during the late fall/early winter and spring, while low numbers of eggs per female and small female size was evident in late spring/summer (Grassle \& Grassle 1974). Tsutsumi \& Kikuchi (1984) also reported seasonal differences in size-specific fecundity, overall brood size and size distributions of brooding $C$. capitata. Levin \& Huggett (1990) found significant seasonal changes in population size-structure, production and life history traits for planktotrophic and lecithotrophic morphs of Streblospio benedicti at 2 sites in North Carolina, USA. Marsh $\&$ Tenore (1990) found declines in growth, female body mass and reproductive effort during summer in an $S$. benedicti population in the Patuxent River, Maryland. Maximal values for these characteristics accurred in early spring (Marsh \& Tenore 1990).

Evidence is accumulating that infaunal opportunists typically show spatial and temporal differences in life history traits and population characteristics, as noted above. Intraspecific differences in life history traits may evolve in response to local selective pressures quickly (Doyle \& Hunte 1981), resulting in the kinds of differences found by Rice \& Simon (1980) in Floridian Polydora ligni populations and on larger spatial scales as indicated by differences between the Alewife Cove population and those studied elsewhere. Opportunists evolve population-specific life history traits in response to local conditions, yet spatially separated populations maintain the potential for exploiting open space following disturbance. Seasonality may integrate local conditions over broader spatial scales and select for adaptations to seasonal pulses in open space, food, levels of competition, etc. Thus seasonality may be a prime evolutionary determinant of opportunistic life history characteristics in $P$. ligni and other opportunistic polychaetes (Zajac 1991).

Acknowledgements. While this work was being done I benefited from the support and stimulation of my Ph.D. dissertation committee: R. B. Whitlatch, J. P. Grassle, S. W. Pacala and J. A. Silander; many colleagues, friends and my family. Financial support was provided, in part, by The American Museum of Natural History Lerner Grey Fund for Marine Research, predoctoral fellowships from the University of Connecticut, and NSF Grant OCE 801447 (to R. B. Whitlatch). Technical support was provided by A. Lima, R. DeGoursey, D. Good, E. Wessels and C. Crouch. Easy access to the study area was provided by the Town of Waterford, Connecticut. The manuscript was improved by comments from E. D. Gallagher, K. Tenore, L. A. Levin, A. Marsh and several anonymous reviewers. To all I extend my deepest thanks.

\section{LITERATURE CITED}

Anger, K., Anger, V., Hagmeier, E. (1986). Laboratory studies on larval growth of Polydora ligni, Polydora cillata, and Pygospio elegans (Polychaeta, Spionidae). Helgoländer Meeresunters. 40: 377-395

Blake, J. A. (1969). Reproduction and larval development of Polydora from northern New England (Polychaeta: Spionidae). Ophelia 7. 1-63

Blake, J. A. (1971). Revision of the genus Polydora from the east coast of North America (Polychaeta: Spionidae). Smithson Contr Zool. 75: 32 pp.

Butman, C. A., Grassle, J. P., Buskey, E. J. (1988). Horizontal swimming and gravitational sinking of Capitella sp. I (Annelida: Polychaeta) larvae: implications for settlement. Ophelia 29: 43-57

Chesney, E. J., Tenore, K. R. (1985a) Oscillations of laboratory populations of the polychaete Capitella capitata (Type I): their cause and implications for natural populations. Mar. Ecol. Prog. Ser 20: 289-296

Chesney, E. J., Tenore, K. R. (1985b). Effects of predation and disturbance on the population growth and dynamics of the polychaete Capitella capitata (Type I). Mar. Biol. 85: $77-82$

Daro, M. H., Polk, P. (1973). The autecology of Polydora ciliata along the Belgian coast. Neth. J. Sea Res. 6: 130-140

Dauer, D. M., Maybury, C. A., Ewing. R. M. (1981). Feeding 
behavior and general ecology of several spionid polychaetes from the Chesapeake Bay. J. exp. mar. Biol. Ecol. 54: 21-38

Dorsett, D. A. (1961). The reproduction and maintenance of Polydora ciliata (Jonhst.) at Whitstable. J. mar biol. Ass. U.K. 41:383-396

Doyle, R. W., Hunte, W. (1981). Demography of an estuarine amphipod (Gammarus lawrencianus) experimentally selected for high ' $r$ ': a model of the genetic effects of environmental change. Can. J. Fish. Aquat. Sci. 38: $1120-1127$

Fonseca-Genevois, V., Cazaux, C. (1987). Streblospio benedicti Webster 1879 (Annelide Polychete) dans L'estaurie de la Loire: biologie et ecologie. Cah. Biol. mar. 28: 231-261

Gallagher, E. D., Jumars, P. A., Trueblood, D. D. (1983). Facilitation of soft-bottom benthic succession by tubebuilders. Ecology 64: 1200-1216

Grassle, J. F., Grassle, J. P. (1974). Opportunistic life histories and genetic systems in marine benthic polychaetes. $J$. mar. Res. 32: 253-284

Grassle, J. F., Grassle, J. P. (1977). Temporal adaptations in sibling species of Capitella. In: Coull, B. C. (ed.) Ecology of marine benthos. University of South Carolina Press, Columbia, p. 177-189

Grassle, J. P., Grassle, J. F. (1976). Sibling species in the marine pollution indicator Capitella (Polychaeta). Science 192: $567-569$

Gremare, A., Marsh, A. G., Tenore, K. R. (1988). Short-term reproductive responses of Capitella sp. I (Annelida: Polychaeta) fed on different diets. J. exp. mar Biol. Ecol. 123: $147-162$

Gremare, A., Marsh, A. G., Tenore, K. R. (1989). Secondary production and reproduction of Capitella capitata type I (Annelida: Polychaeta) during a population cycle. Mar Ecol. Prog. Ser. 51: 99-105

Gudmundsson, H. (1985). Life history patterns of polychaete species of the family Spionidae. J. mar. biol. Ass. U.K. 65 : 93-111

Hannerz, L. (1956). Larval development of the polychaete families Spionidae Sars, Disomidae Mesnil and Poecilochaetidae n. fam. in the Gullmar Fjord (Sweden). Zool. Bijdr. 31: 1-204

Holland, A. F. (1985). Long-term variation of macrobenthos in a mesohaline region of Chesapeake Bay. Estuaries 8-2a: 93-113

Johnson, R. G. (1973). Conceptual models of benthic communities. In: Schopf, T. J. M. (ed.) Models in paleobiology. Freeman Cooper and Co., San Francisco, p. 148-159

Lambeck, R. H. D., Valentijn, P. (1987). Distribution, dynamics and productivity of a colonizing (Polydora quadrilobata) and an established ( $P$. ligni) polydorid polychaete in Lake Grevelingen: an enclosed estuary in the SW Netherlands. Neth. J. Sea Res. 21: 143-158

Levin, L. A. (1984a). Life history and dispersal patterns in a dense infaunal polychaete assemblage: community structure and response to disturbance. Ecology 65: 1185-1200

Levin, L. A. (1984b). Multiple patterns of development in Streblospio benedicti Webster (Spionidae) from three coasts of North America. Biol. Bull. mar biol. Lab., Woods Hole 166: 494-508

Levin, L. A. (1986a). Effects of enrichment on reproduction in the opportunistic polychaete Streblospio benedicti (Webster): a mesocosm study. Biol. Bull. mar biol. Lab., Woods Hole 171: 143-160

Levin, L. A. (1986b). The influence of tides on larval availability in shallow waters overlying a mudflat. Bull. mar. Sci. 39: $224-233$
Levin, L. A., Creed, E. L. (1986). Effect of temperature and food availability on reproductive responses of Streblospio bendicti (Polychaeta: Spionidae) with planktotrophic or lecithotrophic development. Mar. Biol. 92: 103-113

Levin, L. A., Caswell, H., DePatra, K. D., Creed, E. L. (1987). Demographic consequences of larval development mode: planktotrophy vs. lecithotrophy in Streblospio benedicti. Ecology 68: 1877-1886

Levin, L. A., Huggett, D. V (1990). Implications of alternative reproductive modes for seasonality and demography in an estuarine polychaete. Ecology 71: 2191-2208

Levin, L. A., Zhu, J., Creed, E. L. (1991). The genetic basis of life-history characters in a polychaete exhibiting planktotrophy and lecithotrophy. Evolution 45: 380-39?

Marsh, A., Tenore, K. R. $(1990)$. The role of nutrition in regulating the population dynamics of opportunistic, surface-deposit feeders in a mesohaline community. Limnol. Oceanogr 35: 710-723

McCall, P. L. (1977). Community patterns and adaptive strategies of the infaunal benthos of Long Island Sound. J. mar. Res. 35: 221-266

Nichols, F. H., Thompson, J. K. (1985). Persistence of an introduced mudflat community in South San Francisco Bay, California Mar Ecol. Prog. Ser 24: 83-97

Oyenekan, J. A. (1980). Production and population dynamics of Capitella capitata. Arch. Hydrobiol. 98: 115-126

Olive, P. J. W. (1970). Reproduction of a Northumberland population of the polychaete Cirratulus cirratus. Mar Biol. 5: $259-273$

Olive, P. J. W., Clark, R. B. (1978). Physiology of reproduction. In: Mill, P. J. (ed.) Physiology of Annelids. Academic Press, London, p. 271-368

Pearson, T H., Rosenberg, R. (1978). Macrobenthic succession in relation to organic enrichment and pollution of the marine environment. Oceanogr. mar. Biol. A. Rev. 16: 229-311

Redman, C. M. (1984). Effect of temperature and salinity on the life history of Capitella capitata (Type I). Ph.D. dissertation, City University of New York, New York

Rhoads, D. C., Boyer, L. F. (1982). The effects of marine benthos on physical properties of sediments: a successional perspective. In: McCall, P. L., Tevesz, M. J. S. (eds.) Animal-sediment relations. Plenum Publishing, New York, p. $3-52$

Rice, S. A. (1975). The life history of Polydora ligni (Polychaeta: Spionidae) including a summary of reproduction in the family Spionidae. Masters thesis, California State University, Long Beach

Rice, S. A. (1978). Intraspecific variation in the opportunistic polychaete Polydora ligni (Spionidae). Ph.D. dissertation, University of South Florida, Tampa

Rice, S. A., Simon, J. L. (1980). Intraspecific variation in the pollution indicator polychaete Polydora ligni (Spionidae). Ophelia 19: 79-115

SAS (1982). SAS user's guide: statistics. SAS Institute, Cary, North Carolina

Sokal, R. R., Rohlf, F. J. (1981). Biometry. W. H. Freeman and Co., New York

Strathmann, R. R. (1983). Selection for retention or export of larvae in estuaries. In: Kennedy, V (ed.) Estuarine comparisons. Academic Press, New York, p. 521-536

Stancyk, S. E., Feller, R. J. (1986). Transport of non-decapod invertebrate larvae in estuaries: an overview. Bull. mar Sci. 39: 257-268

Tenore, K. R., Chesney, E. J. (1985). The effects of interaction of rate of food supply and population density on the bioenergetics of the opportunistic polychaete Capitella capitata (type I). Limnol. Oceanogr, 30: 1188-1195 
Tsutsumi, H. (1987). Population dynamics of Capitella capitata (Polychaeta; Capitellidae) in an organically polluted cove. Mar Ecol. Prog. Ser. 36: 139-149

Tsutsumi, H., Kikuchi, T. (1984). Study of the life history of Capitella capitata (Polychaeta: Capitellidae) in Amakusa, south Japan including a comparison with other geographical regions. Mar Biol. 80: 315-321

Warren, L. M. (1976). A study of the polychaete Capitella capitata at Plymouth. Mar Biol. 38: 209-216

Watling, L. (1975). Analysis of structural variations in a shallow estuarine deposit feeding community. J. exp. mar. Biol. Ecol. 19: 275-313

Welsh, B. L., Herring, J. P., Read, L. M. (1978). The effects of reduced wetlands and storage basins on the stability of a small Connecticut estuary. In: Wiley, M. L. (ed.) Estuarine interactions. Academic Press, New York, p. 381-401

This article was presented by K. R. Tenore, Solomons, Maryland, USA
Zajac, R. N. (1985). Population dynamics and life history variation in Polydora ligni (Annelida: Polychaeta). Ph.D dissertation, University of Connecticut, Storrs

Zajac, R. N. (1986). The effects of intraspecific density and food supply on growth and reproduction in the infaunal polychaete Polydora ligni. J. mar. Res. 44: 339-359

Zajac, R. N. (1991). Population ecology of Polydora ligni (Polychaeta: Spionidae). II. Seasonal demographic variation and its potential impact on life history evolution. Mar Ecol. Prog. Ser 77. 207-220

Zajac, R. N., Whitlatch, R. B. (1982). Responses of estuarine infauna to disturbance. I. Spatial and temporal variation of initial recolonization. Mar Ecol. Prog. Ser. 10:1-14

Zajac, R. N., Whitlatch, R. B. (1991). Demographic aspects of marine, soft-sediment patch dynamics. Am. Zool. 31 (in press)

Manuscript first received: November 11, 1990

Revised version accepted: August 30, 1991 